\title{
Playing with Our Understandings
}

\author{
SARAH SMITHERMAN PRATT \\ University of North Carolina-Greensboro (USA)
}

\begin{abstract}
The world becomes our representation as we solemnly become the singular representatives of all things. We become, here, the grand colonizers. We become the ones that savage those whom we consider unorganized, uncivilized, illogical, immoral, immature, by rendering them in our own image. We don't allow them a face (difference, here, must be fixed, for to be different is to fail to be at the center); we give them a façade of our own making. Deep in our Western heritage, and threading lines into contemporary educational theory and practice, there is a pleasant, attractive name for this colonization - we wish to understand. (Jardine, $1992 / 2004$, p. 270)
\end{abstract}

David Jardine (1992/2004) questions our very sensibility about what it means to "understand." In the act of understanding, which he claims is a colonizing act, we as educators seek to shape others into our own rendering. When we believe we "understand" something, we are acting upon someone or something else, bringing them into our internal representation of what we have already framed in our minds. Can we truly understand someone if they are different from what we think and believe? Are we not subject to our own limited "understandings" as we impose our interpretations on others?

The word understanding may be common in the current discourse of education research, but the word has been in the English language for centuries. The Oxford English Dictionary (1989) defines understanding as the 
"power of abstract thought; intellect; an individual's perception or judgment of a situation." The root word understand, in verb form, is found as early as the year 888 and interpreted: "to comprehend; to apprehend the meaning or import of; to grasp the idea of." This first definition- "to comprehend" - seems to be the most common interpretation today, but there are many other interpretations found in the O.E.D. (1989). One definition, emerging in the $17^{\text {th }}$ century, is "to stand under; to support or assist; to prop up." As early as 1131, to understand also is interpreted: "to have knowledge of, to know or to learn, by information received," which morphed into "to take or accept as a fact, without positive knowledge or certainty" by the $18^{\text {th }}$ century. These other meanings are distinct in their description and reveal a modernist rationale-relying on the assumption that information passes from one to another, often with a sense of being "presumed" or "accepted" by the one who understands "without positive knowledge" or "specific mention."

This slipperiness of the word understand (which constitutes 10 pages in the O.E.D., 1989) appears in the various adjectives often aligned with the word-solid, mature, real, beginning, states of, degrees of, etc. Furthermore, the dynamics of interpretation are also imposed on the one who is performing the act of understanding - the "understandee" - never questioning the one who determines that understanding has been achieved-the "understander". ${ }^{1}$ The use of understanding in the discourse of educational research, primarily pertaining to constructivist literature, maintains the power dynamics of knower/learner, something that I believe needs to be questioned and (re)considered.

For example, Lee Shulman (1986/2004) highlights some ways in which researchers in teacher education interpret understanding. His mantra of "those who can do; those who understand, teach" (p. 212) reveals his emphasis on the importance of understanding in education. When one reads further, however, it is apparent that his use of language reveals modern, rationalist interpretations that rely on the relationship of "understander" to "understandee." In this interpretative frame, the issue of understanding carries with it the assumption that in the act of "constructing," students acquire a level of understanding, which is assessed by the teacher. Rather than a prescriptive model, Shulman argues that pedagogical content knowledge reflects a teacher's ability to choose wisely what would be the most effective way to engage students in understanding particular subject matter, knowing that this decision is situated within that moment of teaching, a cognitive flexibility (Hiebert and Carpenter, 1992). "Since there are no single most powerful forms of representation," Shulman (1986/2004) claims, "the teacher must have at hand a veritable armamentarium of alternative forms of representation, some of which derive from research whereas others originate in the 
wisdom of practice" (p. 203). In their wisdom, these teachers reveal that they understand-which Shulman describes as pedagogical content knowledge. Shulman considers learning to be in flux, but what still remains unquestioned are the understandings of the teacher-once the "understandee" becomes the "understander." For Shulman a teacher understands if s/ he is able to present or re-present set material in varied ways-to find the most effective way to re-present information. Thus, in Shulman's work, the teacher must be in control, must always be determining what is "best" for the students.

In contrast, Ted Aoki (1996/2005) considers what teaching might mean in tensioned spaces of both "and/not-and," which he calls "a space of conjoining and disrupting, indeed, a generative space of possibilities, a space wherein in tensioned ambiguity newness emerges" (p. 318). For Aoki, a teacher is always speculating, attempting to create tensioned spaces of "both and/not-and." By speculating, notions of openness, contemplation, and opportunities for consideration come into play, but not based on the assumption that what another might consider will already be predicted. These suppositions are a way to encourage multiplicities, a both/and logic-not a logic of either this or that which does not allow for the possibility of both. Aoki (1979/2005) qualifies the logic of either this or that as reductionistic. In his exploration for what it means to be Japanese and Canadian, Aoki recognizes that one possible interpretation could be "the nondialectic either-or attitude" in which he becomes "totalized into either one metaphor or the other.... This totalization is reductionist in that other possible metaphors and perspectives are reduced out" (p. 347). Aoki asserts that in this perspective, "one converts $a$ way of life into the way of life. This sense-making approach is equivalent to opting for a monovision existence" (p. 347). He rejects a monovision existence for the power of double vision. ${ }^{2}$ Instead, Aoki wonders how someone can live in spaces of both/and in which possibilities continue to emerge. Understanding, for Aoki, is never static, fixed, or rigid; rather, understanding is always changing, in flux, continually being renewed.

In a similar spirit, Brent Davis (1996) employs a hermeneutical and phenomenological perspective for understanding "understanding," which he defines as a "dynamic and active process of negotiating and re-negotiating one's world whereby the abstract can never be severed from the concrete" (pp. 202-203). He argues that beyond a cognitive interpretation, understandings are "relationally, contextually, and temporally specific" (p. 200). His definition considers conversations-complex ones-between and among students and teachers. The responsibility of the teacher, in this frame, lies in the willingness of the teacher to be re-positioned, not as knower but as a significant participant. The teacher is in relation to, not over, the students, and together all are "thinking the world together" in imaginative and exciting ways. ${ }^{3}$ This perspective invites collective, momentary, situated knowledge, 
and in this perspective, knowledge is created, not re-presented by teacher to students (Pinar, Reynolds, Slattery, \& Taubman, 1995).

Experiences, interpretations, learning, teaching, epistemologies, all of these are dynamic negotiations that occur in-between, neither yours nor mine, yet both of ours. Here interactions and relationships are vital to creating new moments in which we all both understand / and do not understand. This notion of understanding embraces relationships as part of the adventure of education, but also honors consideration for how we are always situated, how we can create knowledge and information together, and how we are always in relation. Knowledge is the result of a creative act; we understand only in parts, pieces, and only for a fleeting moment, then the moment passes us by, and we wonder if we ever truly understand.

\section{Notes}

1. By using this phrasing, "understandee" and "understander," I am raising the issue of power positions that exist in constructivism. The "understood" in this relationship would be the concept(s) that are being discussed. In constructivism, the teacher is assumed to be the "understander," while the student is situated as the "understandee."

2. In Chapter 2 of Mind and Nature, Gregory Bateson (2002) experiments with the double vision and how perceptions are affected by the possibilities and limitations of what we see, even if it is different from what we know.

3. This phrase, "thinking the world together," is an integral part of the work of David Jardine, Patricia Clifford, and Sharon Friesen (2003).

\section{References}

Aoki, T.T. (2005). Reflections of a Japanese Canadian teacher experiencing ethnicity. In W. Pinar \& R. Irwin (Eds.), Curriculum in a new key: The collected works of Ted T. Aoki (pp. 333-348). Mahwah, NJ: Lawrence Erlbaum. (Original work published 1979).

Aoki, T.T. (2005). Imaginaries of 'East and West': Slippery curricular signifiers in education. In W. Pinar \& R. Irwin (Eds.), Curriculum in a new key: The collected works of Ted T. Aoki (pp. 313-319). Mahwah, NJ: Lawrence Erlbaum. (Original work published 1996).

Bateson, G. (2002). Mind and nature: A necessary unity (5 $5^{\text {th }}$ ed.). Cresskill, NJ: Hampton Press.

Davis, B. (1996). Teaching mathematics: Toward a sound alternative. New York: Garland Publishing.

Hiebert, J., \& Carpenter, T. (1992). Learning and teaching with understanding. In D. Grouws (Ed.), Handbook of research on mathematics teaching and learning (pp. 65-97). New York: Macmillan.

Jardine, D. (1992/ 2004). A bell ringing in the empty sky. In W. Pinar (Ed.), Contemporary curriculum discourses (pp. 262-277). Scottsdale, AZ: Gorsuch Scarisbricks.

Jardine, D., Clifford, P., \& Friesen, S. (2003). Back to the basics of teaching and learning: 
Thinking the world together. Mahwah, NJ: Lawrence Erlbaum.

Oxford English Dictionary. (1989). New York: Oxford University Press.

Pinar, W., Reynolds, W., Slattery, P., \& Taubman, P. (1995). Understanding curriculum. New York: Peter Lang.

Shulman, L. (2004). Those who understand: Knowledge and growth in teaching. In S.

Wilson (Ed.), The wisdom of practice: Essays on learning, teaching, and learning to teach (pp. 187-215). San Francisco: Jossey-Bass.

\section{About the Author}

Sarah Smitherman Pratt completed her Ph.D. at Louisiana State University this past May, under the direction of William Doll. She is currently working as an adjunct professor at the University of North Carolina-Greensboro, teaching mathematics teacher education courses. Email: sspratt@uncg.edu.

(C) Copyright 2006. The author, Sarah Smitherman Pratt, assigns to the University of Alberta and other educational and non-profit institutions a non-exclusive license to use this document for personal use and in courses of instruction provided that the article is used in full and this copyright statement is reproduced. The authors also grant a non-exclusive license to the University of Alberta to publish this document in full on the World Wide Web, and for the document to be published on mirrors on the World Wide Web. Any other usage is prohibited without the express permission of the authors. 
